\title{
Problematyka walidacji metody oznaczania 1,3-butadienu w skroplonych gazach węglowodorowych
}

\author{
The issues of validation of the method for determination of 1,3-butadiene in liquefied \\ hydrocarbon gases
}

\author{
Zygmunt Burnus \\ Instytut Nafty i Gazu - Państwowy Instytut Badawczy
}

\begin{abstract}
STRESZCZENIE: Zgodnie z wymaganiami rozporządzenia Parlamentu Europejskiego i Rady nr 1907/2006 (REACH), zawartymi w dodatkach 1-4, w części dotyczącej obecności substancji rakotwórczych i mutagennych w skroplonych gazach węglowodorowych (LPG), istnieje konieczność oznaczania w tym produkcie zawartości 1,3-butadienu na poziomie poniżej 0,1\% $(\mathrm{m} / \mathrm{m})$. Zawartość 1,3-butadienu poniżej $0,1 \%(\mathrm{~m} / \mathrm{m})$ w LPG znosi jego klasyfikację jako substancji rakotwórczej lub mutagennej. Precyzyjne badanie tak niskiego poziomu zawartości 1,3-butadienu w LPG nie jest jednak możliwe według metody takiej jak PN-EN 27941:2015-12, stosowanej standardowo do badania składu LPG w Unii Europejskiej, ponieważ wyznaczone parametry precyzji metody podane w tej normie są niewystarczające do osiągnięcia tego celu. W związku z powyższym najnowsza specyfikacja europejska dla LPG, opisująca wymagania i metody badań, przywołuje normę niemiecką DIN 51619:2004-02, która umożliwia oznaczanie niskich zawartości 1,3-butadienu, tzn. od $0,01 \%(\mathrm{~m} / \mathrm{m})$. Wspomniana norma powinna zostać wdrożona do praktyki laboratoryjnej oraz akredytowana w polskich laboratoriach zajmujących się badaniami jakościowymi LPG. Walidacja i potwierdzenie możliwości stosowania metody DIN 51619:2004-02 może stanowić duże wyzwanie dla laboratoriów badawczych z uwagi na konieczność oznaczania 1,3-butadienu poniżej 0,1\% ( $\mathrm{m} / \mathrm{m})$ w LPG metodą do tej pory niestosowaną $\mathrm{w}$ warunkach polskich laboratoriów. Szczególny problem może stanowić aparatura do odparowania LPG zastosowana w normie. W niniejszej pracy przedstawiono elementy walidacji i sprawdzenia możliwości stosowania metody oznaczania 1,3-butadienu w skroplonych gazach węglowodorowych LPG według normy DIN 51619:2004-02 w laboratorium analitycznym. Niniejszy artykuł przybliża problematykę walidacji metody, szczególnie pod kątem spełnienia wymagań akredytacyjnych. W artykule zawarto również wyniki badań szeregu próbek LPG pochodzących z polskiego rynku gazu skroplonego LPG, przebadanych pod kątem zawartości 1,3-butadienu. Przedstawione wyniki badań mogą posłużyć do wstępnej oceny poziomu zawartości substancji szkodliwej - 1,3-butadienu w handlowych próbkach LPG występujących na polskim rynku gazu skroplonego.
\end{abstract}

Słowa kluczowe: LPG, 1,3-butadien, chromatografia gazowa.

ABSTRACT: According to the requirements of Regulation (EC) No 1907/2006 of the European Parliament and of the Council (REACH), in the part concerning the presence of carcinogens and mutagens in liquefied hydrocarbon gases (LPG), the necessity of determining the content of 1,3-butadiene at a level below $0.1 \%(\mathrm{~m} / \mathrm{m})$ in this product has been indicated. The content of 1,3 -butadiene below $0.1 \%(\mathrm{~m} / \mathrm{m})$ in LPG abrogates its classification as a carcinogen or mutagen. However, accurate testing of 1,3-butadiene content at such a low level of LPG content is not possible pursuant to a method such as the EN 27941:2015-12 standard used for testing LPG composition in the European Union, because the determined parameters of the method precision given in this standard are insufficient to achieve the purpose. Therefore, the latest European specification for LPG describing the requirements and test methods cites the German standard DIN 51619:2004-02, which allows the determination of low contents of 1,3-butadiene, i.e. from $0.01 \%(\mathrm{~m} / \mathrm{m})$. The mentioned standard should be implemented into laboratory practice and accredited in Polish laboratories dealing with qualitative LPG testing. Validation and confirmation of the possibility of using the DIN 51619:2004-02 method can be a great challenge for research laboratories due to the necessity to determine 1,3-butadiene below $0.1 \%(\mathrm{~m} / \mathrm{m})$ in LPG with a method not previously used in the conditions of Polish laboratories. A particular problem may be the LPG evaporation equipment used in the Standard. This paper presents the elements of validation and checking the possibility of using the method of determination of 1,3-butadiene in liquefied LPG hydrocarbon gases according to DIN 51619:2004-02 in an analytical laboratory. This article outlines the issue of method validation, especially in terms of compliance with accreditation requirements. The article also presents the results of testing a number of LPG samples from the Polish liquefied gas market, tested for 1,3-butadiene. The presented test results can be used for the initial assessment of the level of content of the harmful 1,3-butadiene in commercial LPG samples found on the Polish liquefied gas market.

Key words: LPG, 1,3-butadiene, gas chromatography.

Autor do korespondencji: Z. Burnus, e-mail: zygmunt.burnus@inig.pl

Artykuł nadesłano do Redakcji: 07.01.2020 r. Zatwierdzono do druku: 01.07.2020 r. 


\section{Wstęp}

Instytut Nafty i Gazu - Państwowy Instytut Badawczy co roku prowadzi prace obejmujące tematyką skroplone gazy węglowodorowe LPG (ang. liquefied petroleum gases), mające wpływ na jakość LPG obecnego na rynku europejskim gazu skroplonego. Badania wykonane w Instytucie dotyczyły do tej pory między innymi tematyki normalizacyjnej opracowania nowych metod badań i prac nad aktualizacjami wydań norm (Błaszkiewicz i Rogowska, 2016), badano również wpływ właściwości komponentów LPG na jakość produktu finalnego, wraz z symulacją komponowania gazu skroplonego LPG (Rogowska i Pałuchowska, 2009). Instytut stwierdził także, jakie zagrożenia jakości LPG występują na rynku gazu skroplonego (Danek, 2010), wskazano przy tym na zanieczyszczenia chemiczne i niewłaściwy skład LPG, a szczególnie na wpływ zawartości propanu na względną prężność par LPG. W badaniach Instytutu istotne było również bezpieczeństwo pracy z LPG, stanowiącym łatwopalną mieszaninę gazów (Haduch, 2009). Badania LPG na polskim rynku gazu skroplonego oceniono ponadto poprzez opisanie problematyki badań międzylaboratoryjnych LPG (Burnus, 2012). W poprzedniej pracy autora opisano problematykę walidacji metody oznaczania rozpuszczalnej pozostałości LPG (Burnus, 2009).

Handlowe próbki LPG obecne na polskim rynku gazu skroplonego bada się corocznie $\mathrm{w}$ ramach systemu monitorowania jakości paliw na podstawie rozporządzeń Ministra Energii w sprawie wymagań jakościowych dla gazu skroplonego LPG (Dz.U. z 2016 r. poz. 540) oraz w sprawie metod badania gazu skroplonego LPG (Dz.U. z 2017 r. poz. 159).

Stosowana w laboratoriach badawczych norma PN-EN 27941:2015-12, dotycząca oznaczania składu węglowodorowego skroplonych gazów węglowodorowych (LPG), umożliwia oznaczanie ilościowe składników LPG techniką chromatografii gazowej. Przy użyciu tej normy możliwe jest oznaczenie węglowodorów od $\mathrm{C}_{1}$ do $\mathrm{C}_{5}$. Jej granica oznaczalności wynosi $0,1 \%(\mathrm{~m} / \mathrm{m})$.

Wymagania rozporządzenia REACH (rozporządzenie (WE) nr 1907/2006) przywołują 1,3-butadien (nr CAS 203-450-8) w dodatkach 1 i 4, w pozycjach 28 i 29, które dotyczą substancji rakotwórczych i mutagennych. Zgodnie ze wspomnianymi wymaganiami, w uwadze $\mathrm{K}$ do powyższych dodatków, klasyfikacja substancji jako rakotwórczej lub mutagennej nie jest konieczna, gdy wykaże się, że klasyfikowana substancja zawiera poniżej $0,1 \%(\mathrm{~m} / \mathrm{m}) 1,3$-butadienu. W związku z powyższym ten związek organiczny, jako substancja szczególnie szkodliwa, powinien być oznaczany precyzyjnie na poziomie poniżej $0,1 \%(\mathrm{~m} / \mathrm{m})$ do celów prawidłowej klasyfikacji substancji. Wymieniona norma PN-EN 27941:2015-12 nie może być zastosowana $\mathrm{w}$ tym celu $\mathrm{z}$ uwagi na brak wyznaczonych wartości precyzji na poziomie poniżej $0,1 \%(\mathrm{~m} / \mathrm{m})$.

$\mathrm{Z}$ tego powodu w najnowszej specyfikacji dla LPG, $\mathrm{tj}$. PN-EN 589:2019:04, w tabeli 1 „Wymagania i metody badań" powołano normę DIN 51619:2004-02 w pozycji dotyczącej oznaczania całkowitej zawartości dienów, 1,3-butadienu oraz zawartości propanu. Norma DIN 51619:2004-02 podaje wartości precyzji wyznaczonej dla pomiaru zawartości 1,3-butadienu już od $0,01 \%(\mathrm{~m} / \mathrm{m})$. Nadaje się zatem do oceny substancji zgodnie w wymaganiami rozporządzenia REACH w zakresie zawartości 1,3-butadienu.

W przypadku parametrów: całkowita zawartość dienów oraz zawartość propanu możliwe jest zastosowanie w laboratorium metodyki oznaczania składu LPG według normy PN-EN 27941:2015-12, poprzedzone jej wdrożeniem do praktyki laboratoryjnej i akredytacją. Z kolei oznaczenie 1,3-butadienu wymaga zastosowania wyłącznie normy DIN 51619:2004-02, która powinna być wdrożona do stosowania w laboratoriach.

W większości przypadków norma DIN 51619:2004-02 nie może być bezpośrednio wykorzystana w laboratorium z uwagi na konieczność dodatkowego wyposażenia chromatografu gazowego, które opisano w wymienionej normie. W związku z powyższym konieczne jest przeprowadzenie szeregu działań w celu dostosowania aparatury będącej na wyposażeniu laboratorium do oznaczania składu LPG, ze szczególnym uwzględnieniem 1,3-butadienu w LPG.

\section{Aparatura badawcza do oznaczania składu LPG oraz 1,3-butadienu według normy DIN 51619:2004-02}

W niniejszej pracy do celów badawczych zastosowano chromatograf gazowy Agilent Technologies - model 7890B. Chromatograf był wyposażony w system automatycznej regulacji ciśnienia gazu nośnego oraz gazów zasilających detektor, termostat na kolumny chromatograficzne, butle z gazami sprężonymi wysokiej czystości.

W celu dostosowania chromatografu Agilent Technologies - model 7890B do potrzeb oznaczania składu węglowodorowego LPG, w tym głównie do oznaczania zawartości 1,3-butadienu według normy DIN 51619:2004-02, konieczne było zainstalowanie w nim tzw. opcji zaworowej. Chromatograf został wyposażony w zawór dozujący LPG w postaci gazowej (6-portowy) z połączeniami zawór-dozownik wraz $\mathrm{z}$ termostatem, w kolumnę CP-AL2O3/KCL o wymiarach $50 \mathrm{~m} \times 0,53 \mathrm{~mm} \times 10 \mu \mathrm{m}$ wraz ze złączką kolumny $0,53 \mathrm{~mm}$ do zaworu. Zestaw do odparowania LPG według normy DIN 51619:2004-02 składał się z łaźni wodnej termostatującej o zakresie regulacji temperatury od $70^{\circ} \mathrm{C}$ do $100^{\circ} \mathrm{C}$ i utrzymywaniu temperatury z dokładnością około $1^{\circ} \mathrm{C}$ do termostatowania 
pętli do odparowania próbki LPG oraz z przewodów stalowych do odparowania LPG, wykonanych ze stali nierdzewnej: rurka 3,5 m fi wewn. 0,5 mm oraz rurka o długości 3,0 m fi wewn. 1,0 mm, zaopatrzonych w zawory regulacyjne oraz złączki umożliwiające podłączenie rurki do zaworu dozującego oraz do pojemnika z próbką.

Skompletowanie wymienionego zestawu umożliwiło poprawne odparowanie próbki LPG w warunkach termostatowanych. Jest ono możliwe przy wykorzystaniu dowolnego rozwiązania dostępnego na rynku. Na zastosowanym sprzęcie uzyskano również powtarzalne dozowanie próbki gazowej przy użyciu dozownika 6-portowego. Powtarzalność oceniono wstępnie na podstawie otrzymywanego odchylenia standardowego pomiędzy kolejnymi pomiarami jednej z próbek rzeczywistych. Powtarzalność wyznaczona na podstawie powyższego odchylenia mieściła się w wartości granicznej powtarzalności podanej w normie DIN 51619:2004-02. Kolumna chromatograficzna umożliwiła rozdział poszczególnych składników gazu LPG. Faza stacjonarna $\mathrm{Al}_{2} \mathrm{O}_{3} / \mathrm{KCl}$, zastosowana w kolumnie kapilarnej do chromatografii gazowej w opisywanym zestawie, zapewniła selektywny rozdział pomiędzy pikami węglowodorów, w szczególności 1,3-butadienu od pozostałych składników próbki LPG, co umożliwiło uzyskanie niskiej granicy oznaczalności dla tego składnika. Zidentyfikowano kluczowe czynniki umożliwiające uzyskanie, wymaganej według normy DIN 51619:2004-02, wartości powtarzalności oznaczania składu LPG, w tym 1,3-butadienu. Bardzo istotne okazało się zastosowanie zaworu regulacyjnego przed łaźnią wodną. Zawór ten umożliwił ustawienie przepływu próbki LPG przez linię do odparowania. Konieczny był również precyzyjny pomiar przepływu (3000 $\mathrm{ml} / \mathrm{min})$, podanego w normie DIN 51619:2004-02, mierzonego dla próbki LPG na wylocie z zaworu dozującego.

\section{Warunki wykonywania oznaczeń składu LPG pod kątem niskich zawartości 1,3-butadienu}

Do oznaczania składu węglowodorowego próbek LPG, ze szczególnym uwzględnieniem 1,3-butadienu, przyjęto następujące warunki oznaczania, oparte na przykładowych wielkościach podanych w normie DIN 51619:2004-02:

- 6-portowy dozownik w postaci zaworu z pętlą, objętość pętli dozującej: $0,5 \mathrm{ml}$;

- łaźnia wodna termostatowana w temperaturze $85^{\circ} \mathrm{C}$ (środek zakresu $70-100^{\circ} \mathrm{C}$, wymaganego w normie DIN 51619:2004-02);

- czas płukania pętli dozującej próbką: 2 minuty;

- temperatura dozownika split: $200^{\circ} \mathrm{C}$, przepływ split: $250 \mathrm{ml} / \mathrm{min}$, przepływ septum purge: $3 \mathrm{ml} / \mathrm{min}$;
- program temperaturowy termostatu: przyrost temperatury od $50^{\circ} \mathrm{C}$ do $120^{\circ} \mathrm{C}$ z szybkością $4^{\circ} \mathrm{C} / \mathrm{min}$, izoterma końcowa $120^{\circ} \mathrm{C}$ przez 10 minut;

- program ciśnienia gazu nośnego: przyrost ciśnienia od $33 \mathrm{kPa}$ do $44 \mathrm{kPa}$ z szybkością 0,5 kPa, izobara końcowa $44 \mathrm{kPa}$ przez 20 minut;

- detektor płomieniowo-jonizacyjny FID, temperatura $225^{\circ} \mathrm{C}$. Każdorazowe sprawdzenie integracji automatycznej chromatogramu wykonywanej przez program komputerowy jest działaniem standardowym przy pracy laboratoryjnej z jakimkolwiek rodzajem chromatografii. W przypadku tego oznaczenia zalecana jest integracja do linii bazowej.

\section{Sprawdzenie możliwości stosowania metody DIN 51619:2004-02 - elementy walidacji metody}

Pierwszym etapem potwierdzenia możliwości stosowania metody chromatograficznej jest wyznaczenie czasów retencji badanych substancji. W niniejszej pracy wykorzystano certyfikowane materiały wzorcowe - mieszaniny wagowe gazów skroplonych - pozyskane z S.I.A.D. S.p.A. (Włochy) oraz Air Products, N.V./S.A. (Belgia).

W celu przeprowadzenia oceny poprawności działania systemu chromatograficznego wykonano trzy oznaczenia dla wybranej próbki wzorcowej LPG (S.I.A.D. S.p.A.), zawierającej wszystkie składniki węglowodorowe obecne w typowej próbce gazu skroplonego. Chromatogramy poddano integracji ręcznej, odczytano czasy retencji pików, obliczono średnią wartość czasu retencji dla każdego ze składników węglowodorowych. Uzyskane czasy retencji były identyczne w kolejnych oznaczeniach przy dokładności do $0,01 \mathrm{~min}$. W dłuższym okresie, z uwagi na bleeding kolumny, tzn. ucieczkę fazy stacjonarnej z kolumny, czasy te mogą ulec skróceniu. Zalecana jest zatem okresowa kontrola czasów retencji poprzez wykonanie badania wybranej próbki kontrolnej lub wzorcowej LPG. Otrzymane wartości średnich czasów retencji podano w tabeli 1. Chromatogram z oznaczenia składu wzorcowej mieszaniny gazów skroplonych LPG przedstawiono na rysunku 1.

Zaobserwowano bardzo dobrą rozdzielczość pomiędzy pikiem 1,3-butadienu (wskazany na rys. 1) a pozostałymi składnikami LPG. Uzyskano wysoką selektywność oznaczenia 1,3-butadienu w LPG przy zastosowaniu niniejszego zestawu, zgodnego z DIN 51619:2004-02. Istnieje możliwość zastosowania innej kolumny chromatograficznej o podobnej charakterystyce, z zachowaniem identycznej długości kolumny $(50 \mathrm{~m})$, średnicy wewnętrznej $(0,53 \mathrm{~mm})$ i grubości filmu fazy stacjonarnej (10 $\mu \mathrm{m})$. W przypadku użycia innej kolumny konieczne jest sprawdzenie rozdzielczości pomiędzy pikiem 
Tabela 1. Wartości średnie czasów retencji uzyskane dla węglowodorów oznaczanych w LPG

Table 1. Average values of retention times obtained for hydrocarbons determined in LPG

\begin{tabular}{|c|c|}
\hline \multirow{2}{*}{$\begin{array}{c}\text { Składnik węglowodorowy } \\
\text { gazu skroplonego LPG }\end{array}$} & Wyznaczony średni czas retencji \\
\cline { 2 - 2 } & [minuty] \\
\hline \hline Metan & 3,64 \\
\hline Etan & 4,18 \\
\hline Eten & 4,77 \\
\hline Propan & 6,15 \\
\hline Propen & 9,03 \\
\hline i-butan & 11,05 \\
\hline n-butan & 11,76 \\
\hline 2-trans-buten & 15,55 \\
\hline 1-buten & 15,92 \\
\hline i-buten & 16,53 \\
\hline 2-cis-buten & 17,19 \\
\hline 1,2-butadien & 19,64 \\
\hline i-pentan & 19,70 \\
\hline n-pentan & 20,55 \\
\hline 1,3-butadien & 21,24 \\
\hline & \\
\hline & \\
\hline & \\
\hline
\end{tabular}

Rys. 1. Chromatogram z analizy wzorcowej mieszaniny gazów skroplonych LPG

Fig. 1. Standard analysis chromatogram of an LPG liquefied gas mixture

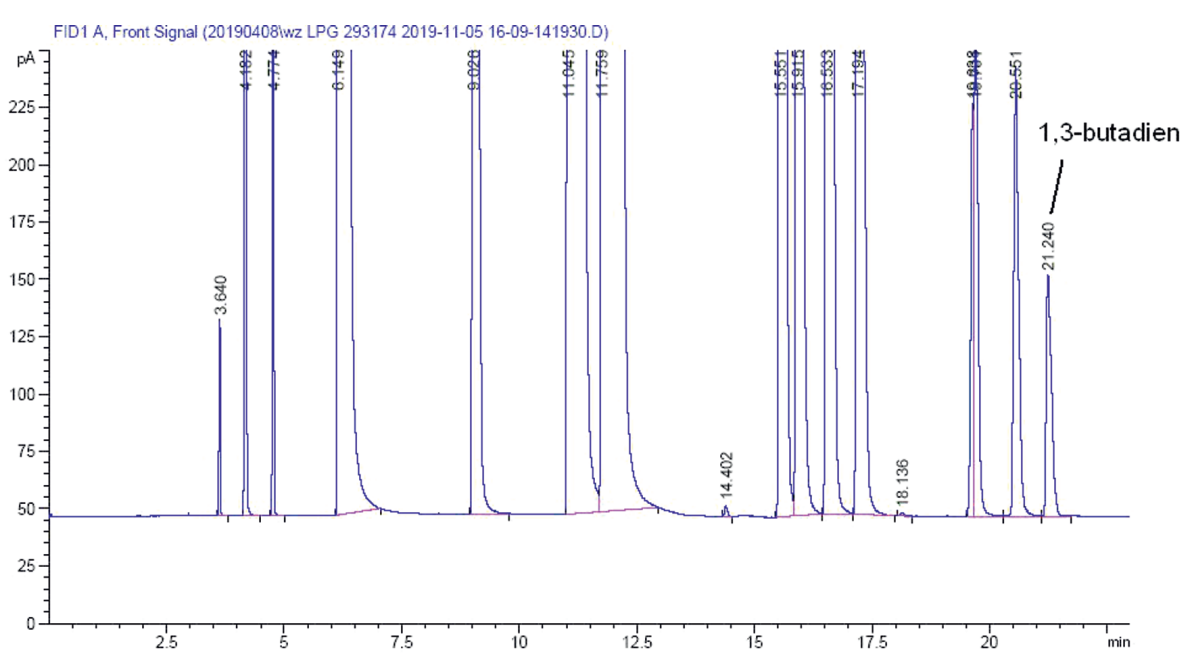

oznaczane składniki gazu skroplonego LPG oraz 1,3-butadien (Air Products, N.V./S.A. - Belgia).

W celu wyznaczenia współczynników odpowiedzi wykonuje się co najmniej pięć oznaczeń dla próbki wzorcowej LPG, zawierającej składniki węglowodorowe o określonej zawartości. Chromatogramy poddaje się integracji ręcznej, odczytuje się procentowe powierzchnie pików i oblicza się średnią wartość procentowej powierzchni dla każdego ze składników węglowodorowych LPG. Następnie oblicza się współczynniki odpowiedzi detektora płomieniowo-jonizacyjnego FID jako iloraz uzyskanej wartości średniej procentowej powierzchni piku i wartości certyfikowanej.

Wyznaczone współczynniki posłużyły do obliczania procentowej zawartości składników węglowodorowych w badanych próbkach rzeczywistych gazu skroplonego LPG.

Jednym z najważniejszych etapów oceny precyzji metody jest wyznaczenie lub sprawdzenie powtarzalności metodyki badania. Aby określić możliwość stosowania metodyki DIN 51619:2004-02 w laboratorium, dokonano sprawdzenia powtarzalności metodyki. W tym celu wykonano po sześć oznaczeń próbek LPG o zróżnicowanej zawartości 1,3-butadienu, od $0,01 \%(\mathrm{~m} / \mathrm{m})$ do $0,24 \%(\mathrm{~m} / \mathrm{m})$. Otrzymane chromatogramy poddano integracji ręcznej, odczytano procentowe powierzchnie pików, obliczono wartość procentowej zawartości każdego składnika w LPG.

Obliczono odchylenie standardowe dla wartości średniej, następnie obliczono powtarzalność zgodnie z normą ASTM E 691 według wzoru (1):

$$
r_{o b l}=2,8 \cdot s
$$

gdzie:

$s$ - odchylenie standardowe.

Otrzymane wartości powtarzalności dla węglowodorów w gazie skroplonym LPG wraz z uzyskanymi wartościami powtarzalności podano $\mathrm{w}$ tabelach 2-6.

Wszystkie otrzymane wartości wy1,3-butadienu i pozostałych składników węglowodorowych próbki. Norma DIN 51619:2004-02 nie podaje wymagania minimalnej rozdzielczości pomiędzy pikami chromatograficznymi, jednakże za dobrą praktykę chromatograficzną należy uznać uzyskanie współczynników rozdziału powyżej 1,5, tak jak wskazano w normie dotyczącej badania składu LPG według PN-EN 27941:2015-12.

Do poprawnego wykonania oznaczenia składu LPG konieczne jest wyznaczenie współczynników odpowiedzi detektora FID dla poszczególnych składników LPG przy zastosowaniu mieszaniny wzorcowej, zawierającej wszystkie znaczonej powtarzalności mieściły się $\mathrm{w}$ zakresie powtarzalności podanej w normie DIN 51619:2004-02. Co jest szczególnie istotne, uzyskano bardzo niskie wartości powtarzalności dla 1,3-butadienu. We wszystkich przypadkach wartość względnego odchylenia standardowego nie przekraczała wartości 3\%, co świadczy o wysokiej precyzji oznaczania metody, szczególnie w przypadku oznaczania 1,3-butadienu. Zakres wyznaczenia powtarzalności wyniósł $0,01 \%(\mathrm{~m} / \mathrm{m})$ do $0,24 \%(\mathrm{~m} / \mathrm{m})$. Metoda pozwala zatem na uzyskiwanie powtarzalnych wyników na niskim poziomie zawartości 1,3-butadienu. Na podstawie uzyskanych wyników badań można 
Tabela 2. Sprawdzenie precyzji metody oznaczania składu gazu skroplonego LPG o zawartości 0,01\% ( $\mathrm{m} / \mathrm{m})$ 1,3-butadienu według normy DIN 51619:2004-02

Table 2. Checking the precision of the method for determination of the composition of LPG liquefied gas with a $0.01 \%(\mathrm{~m} / \mathrm{m})$ content of 1,3-butadiene according to DIN 51619:2004-02

\begin{tabular}{|c|c|c|c|c|}
\hline \multirow{2}{*}{$\begin{array}{l}\text { Składnik węglowodorowy } \\
\text { gazu skroplonego LPG }\end{array}$} & $\begin{array}{c}\text { Średnia oznaczona } \\
\text { zawartość }\end{array}$ & \multirow{2}{*}{$\begin{array}{c}\text { Odchylenie } \\
\text { standardowe } s\end{array}$} & $\begin{array}{c}\text { Powtarzalność } r \text {, obliczona } \\
\text { wedlug ASTM E } 691\end{array}$ & $\begin{array}{l}\text { Powtarzalność } r \text {, obliczona } \\
\text { według normy DIN 51619:2004-02 }\end{array}$ \\
\hline & {$[\%(m / m)]$} & & {$[\%(m / m)]$} & {$[\%(m / m)]$} \\
\hline Metan & 0,01 & 0,000980 & 0,003 & 0,01 \\
\hline Etan & 1,36 & 0,025565 & 0,072 & 0,10 \\
\hline Eten & 0,00 & 0,000064 & 0,000 & 0,01 \\
\hline Propan & 60,39 & 0,108442 & 0,300 & 0,30 \\
\hline Propen & 0,23 & 0,002375 & 0,007 & 0,05 \\
\hline i-butan & 13,98 & 0,058974 & 0,165 & 0,20 \\
\hline n-butan & 23,47 & 0,054270 & 0,152 & 0,20 \\
\hline 2-trans-buten & 0,10 & 0,000535 & 0,001 & 0,05 \\
\hline 1-buten & 0,10 & 0,000559 & 0,002 & 0,05 \\
\hline i-buten & 0,10 & 0,000571 & 0,002 & 0,05 \\
\hline 2-cis-buten & 0,07 & 0,000499 & 0,001 & 0,01 \\
\hline 1,2-butadien & 0,04 & 0,003057 & 0,009 & 0,01 \\
\hline i-pentan & 0,06 & 0,000099 & 0,000 & 0,01 \\
\hline n-pentan & 0,06 & 0,002321 & 0,006 & 0,01 \\
\hline 1,3-butadien & 0,01 & 0,000125 & 0,000 & 0,01 \\
\hline
\end{tabular}

Tabela 3. Sprawdzenie precyzji metody oznaczania składu gazu skroplonego LPG o zawartości 0,03\% ( $\mathrm{m} / \mathrm{m})$ 1,3-butadienu według normy DIN 51619:2004-02

Table 3. Checking the precision of the method for determination of the composition of LPG liquefied gas with a $0.03 \%(\mathrm{~m} / \mathrm{m})$ content of 1,3-butadiene according to DIN 51619:2004-02

\begin{tabular}{|c|c|c|c|c|}
\hline \multirow{2}{*}{$\begin{array}{l}\text { Składnik węglowodorowy } \\
\text { gazu skroplonego LPG }\end{array}$} & $\begin{array}{c}\text { Średnia oznaczona } \\
\text { zawartość }\end{array}$ & \multirow{2}{*}{$\begin{array}{l}\text { Odchylenie } \\
\text { standardowe }\end{array}$} & $\begin{array}{l}\text { Powtarzalność obliczona } \\
\text { według ASTM E } 691\end{array}$ & $\begin{array}{c}\text { Powtarzalność obliczona według } \\
\text { normy DIN 51619:2004-02 }\end{array}$ \\
\hline & {$[\%(m / m)]$} & & {$[\%(m / m)]$} & {$[\%(m / m)]$} \\
\hline Metan & 0,00 & 0,000510 & 0,001 & 0,01 \\
\hline Etan & 1,11 & 0,023340 & 0,065 & 0,10 \\
\hline Eten & 0,01 & 0,000010 & 0,000 & 0,01 \\
\hline Propan & 60,58 & 0,073467 & 0,206 & 0,30 \\
\hline Propen & 0,76 & 0,006812 & 0,019 & 0,05 \\
\hline i-butan & 12,82 & 0,031450 & 0,088 & 0,20 \\
\hline n-butan & 23,10 & 0,013351 & 0,037 & 0,20 \\
\hline 2-trans-buten & 0,36 & 0,002364 & 0,007 & 0,05 \\
\hline 1-buten & 0,30 & 0,001935 & 0,005 & 0,05 \\
\hline i-buten & 0,32 & 0,005823 & 0,016 & 0,05 \\
\hline 2-cis-buten & 0,27 & 0,002151 & 0,006 & 0,05 \\
\hline 1,2-butadien & 0,09 & 0,000084 & 0,000 & 0,01 \\
\hline i-pentan & 0,12 & 0,004886 & 0,014 & 0,05 \\
\hline n-pentan & 0,13 & 0,002339 & 0,007 & 0,05 \\
\hline 1,3-butadien & 0,03 & 0,000556 & 0,002 & 0,01 \\
\hline
\end{tabular}


Tabela 4. Sprawdzenie precyzji metody oznaczania składu gazu skroplonego LPG o zawartości 0,06\% ( $\mathrm{m} / \mathrm{m})$ 1,3-butadienu według normy DIN 51619:2004-02

Table 4. Checking the precision of the method for determination of the composition of LPG liquefied gas with a $0.06 \%(\mathrm{~m} / \mathrm{m})$ content of 1,3-butadiene according to DIN 51619:2004-02

\begin{tabular}{|c|c|c|c|c|}
\hline \multirow{2}{*}{$\begin{array}{l}\text { Składnik węglowodorowy } \\
\text { gazu skroplonego LPG }\end{array}$} & $\begin{array}{l}\text { Średnia oznaczona } \\
\text { zawartość }\end{array}$ & \multirow{2}{*}{$\begin{array}{l}\text { Odchylenie } \\
\text { standardowe }\end{array}$} & $\begin{array}{l}\text { Powtarzalność obliczona } \\
\text { według ASTM E } 691\end{array}$ & $\begin{array}{c}\text { Powtarzalność obliczona według } \\
\text { normy DIN 51619:2004-02 }\end{array}$ \\
\hline & {$[\%(m / m)]$} & & {$[\%(m / m)]$} & {$[\%(m / m)]$} \\
\hline Metan & 0,01 & 0,000781 & 0,002 & 0,01 \\
\hline Etan & 1,36 & 0,028712 & 0,080 & 0,10 \\
\hline Eten & 0,02 & 0,003134 & 0,009 & 0,01 \\
\hline Propan & 58,71 & 0,060340 & 0,169 & 0,30 \\
\hline Propen & 1,12 & 0,006807 & 0,019 & 0,10 \\
\hline i-butan & 13,24 & 0,037264 & 0,104 & 0,20 \\
\hline n-butan & 22,74 & 0,042449 & 0,119 & 0,20 \\
\hline 2-trans-buten & 0,68 & 0,005804 & 0,016 & 0,05 \\
\hline 1-buten & 0,56 & 0,003930 & 0,011 & 0,05 \\
\hline i-buten & 0,58 & 0,004985 & 0,014 & 0,05 \\
\hline 2-cis-buten & 0,51 & 0,006482 & 0,018 & 0,05 \\
\hline 1,2-butadien & 0,10 & 0,005984 & 0,017 & 0,05 \\
\hline i-pentan & 0,15 & 0,006901 & 0,019 & 0,05 \\
\hline n-pentan & 0,16 & 0,005840 & 0,016 & 0,05 \\
\hline 1,3-butadien & 0,06 & 0,001577 & 0,004 & 0,01 \\
\hline
\end{tabular}

Tabela 5. Sprawdzenie precyzji metody oznaczania składu gazu skroplonego LPG o zawartości 0,16\% ( $\mathrm{m} / \mathrm{m})$ 1,3-butadienu według normy DIN 51619:2004-02

Table 5. Checking the precision of the method for determination of the composition of LPG liquefied gas with a $0.16 \%(\mathrm{~m} / \mathrm{m})$ content of 1,3-butadiene according to DIN 51619:2004-02

\begin{tabular}{|c|c|c|c|c|}
\hline \multirow{2}{*}{$\begin{array}{l}\text { Składnik węglowodorowy } \\
\text { gazu skroplonego LPG }\end{array}$} & $\begin{array}{l}\text { Średnia oznaczona } \\
\text { zawartość }\end{array}$ & \multirow{2}{*}{$\begin{array}{l}\text { Odchylenie } \\
\text { standardowe }\end{array}$} & $\begin{array}{c}\text { Powtarzalność obliczona } \\
\text { według ASTM E } 691\end{array}$ & $\begin{array}{c}\text { Powtarzalność obliczona według } \\
\text { normy DIN 51619:2004-02 }\end{array}$ \\
\hline & {$[\%(m / m)]$} & & {$[\%(m / m)]$} & {$[\%(m / m)]$} \\
\hline Metan & 0,03 & 0,000035 & 0,000 & 0,01 \\
\hline Etan & 1,18 & 0,031535 & 0,088 & 0,10 \\
\hline Eten & 0,07 & 0,000076 & 0,000 & 0,01 \\
\hline Propan & 50,21 & 0,030103 & 0,084 & 0,30 \\
\hline Propen & 2,46 & 0,019900 & 0,056 & 0,10 \\
\hline i-butan & 15,77 & 0,014282 & 0,040 & 0,20 \\
\hline n-butan & 23,09 & 0,045648 & 0,128 & 0,20 \\
\hline 2-trans-buten & 1,88 & 0,029496 & 0,083 & 0,10 \\
\hline 1-buten & 1,50 & 0,033527 & 0,094 & 0,10 \\
\hline i-buten & 1,57 & 0,029947 & 0,084 & 0,10 \\
\hline 2-cis-buten & 1,38 & 0,030270 & 0,085 & 0,10 \\
\hline 1,2-butadien & 0,19 & 0,008283 & 0,023 & 0,05 \\
\hline i-pentan & 0,23 & 0,011912 & 0,033 & 0,05 \\
\hline n-pentan & 0,29 & 0,004423 & 0,012 & 0,05 \\
\hline 1,3-butadien & 0,16 & 0,002598 & 0,007 & 0,05 \\
\hline
\end{tabular}


Tabela 6. Sprawdzenie precyzji metody oznaczania składu gazu skroplonego LPG o zawartości 0,24\% ( $\mathrm{m} / \mathrm{m})$ 1,3-butadienu według normy DIN 51619:2004-02

Table 6. Checking the precision of the method for determination of the composition of LPG liquefied gas with a $0.24 \%(\mathrm{~m} / \mathrm{m})$ content of 1,3-butadiene according to DIN 51619:2004-02

\begin{tabular}{|c|c|c|c|c|}
\hline \multirow{2}{*}{$\begin{array}{l}\text { Składnik węglowodorowy } \\
\text { gazu skroplonego LPG }\end{array}$} & $\begin{array}{l}\text { Średnia oznaczona } \\
\text { zawartość }\end{array}$ & \multirow{2}{*}{$\begin{array}{l}\text { Odchylenie } \\
\text { standardowe }\end{array}$} & $\begin{array}{c}\text { Powtarzalność obliczona } \\
\text { według ASTM E } 691\end{array}$ & $\begin{array}{c}\text { Powtarzalność obliczona według } \\
\text { normy DIN 51619:2004-02 }\end{array}$ \\
\hline & {$[\%(m / m)]$} & & {$[\%(m / m)]$} & {$[\%(m / m)]$} \\
\hline Metan & "0,03 & 0,001850 & 0,005 & 0,01 \\
\hline Etan & 1,10 & 0,031396 & 0,088 & 0,10 \\
\hline Eten & 0,14 & 0,005090 & 0,014 & 0,05 \\
\hline Propan & 43,03 & 0,012975 & 0,036 & 0,30 \\
\hline Propen & 3,57 & 0,021395 & 0,060 & 0,10 \\
\hline i-butan & 17,68 & 0,068719 & 0,192 & 0,20 \\
\hline n-butan & 23,84 & 0,038109 & 0,107 & 0,20 \\
\hline 2-trans-buten & 2,78 & 0,028671 & 0,080 & 0,10 \\
\hline 1-buten & 2,22 & 0,016911 & 0,047 & 0,10 \\
\hline i-buten & 2,31 & 0,018205 & 0,051 & 0,10 \\
\hline 2-cis-buten & 2,06 & 0,021629 & 0,061 & 0,10 \\
\hline 1,2-butadien & 0,24 & 0,010286 & 0,029 & 0,05 \\
\hline i-pentan & 0,34 & 0,013568 & 0,038 & 0,05 \\
\hline n-pentan & 0,40 & 0,006011 & 0,017 & 0,05 \\
\hline 1,3-butadien & 0,24 & 0,002184 & 0,006 & 0,05 \\
\hline
\end{tabular}

dodatkowo stwierdzić, że metoda cechuje się niskimi wartościami powtarzalności dla składników o szczególnie niskich poziomach stężeń $\mathrm{w}$ próbce LPG. W przypadku laboratorium badawczego uzyskanie wartości precyzji oznaczania mieszczących się $\mathrm{w}$ granicach podanych $\mathrm{w}$ normie jest konieczne dla prawidłowej oceny gazu skroplonego pod kątem jego składu, a szczególnie zawartości 1,3-butadienu.

Jako element walidacji zbadano obciążenie metody DIN 51619:2004-02 dla oznaczania 1,3-butadienu (tabela 7). Badanie odzysku wykonano, analizując certyfikowany materiał odniesienia CRM (S.I.A.D. S.p.A.). Zbadano odzysk dla próbki certyfikowanego materiału odniesienia o deklarowanym przez producenta stężeniu 1,3-butadienu 0,2395 $\pm 0,0041 \%(\mathrm{~m} / \mathrm{m})$.

Tabela 7. Wyznaczenie wartości odzysku dla 1,3-butadienu

Table 7. Determination of the recovery factor for 1,3-butadiene

\begin{tabular}{|c|c|}
\hline Parametr & CRM \\
\hline \hline & 0,237 \\
$x_{i}$ & 0,239 \\
& 0,236 \\
& 0,239 \\
\hline $\bar{x}$ & 0,236 \\
\hline$x_{\text {odn }}$ & 0,237 \\
\hline$x_{\text {odzys }}$ & 0,2395 \\
\hline
\end{tabular}

Wartość odzysku $x_{\text {odzzsk }}$ jest bliska 1 , zatem metoda nie jest obciążona proporcjonalnym błędem systematycznym w badanym zakresie stężeń. Uzyskano bardzo dobrą zgodność otrzymanego wyniku z wartością deklarowaną, w granicach dopuszczalnego odchylenia.

Następnie wyznaczono granicę wykrywalności LD (ang. limit of detection) oraz granicę oznaczalności LQ (ang. limit of quantification) dla oznaczania 1,3-butadienu w gazie skroplonym LPG według normy DIN 51619:2004-02. Przyjęto LD jako wartość sześciu odchyleń standardowych próby ślepej $6 \cdot s_{p}$, a LQ jako wartość dziesięciu odchyleń standardowych próby ślepej $10 \cdot s_{p}$.

W tabeli 8 przedstawiono wyniki oznaczenia ślepej próby metodą DIN 51619:2004-02 oraz obliczone wartości LD i LQ.

Tabela 8. Wyznaczenie wartości LD i LQ dla 1,3-butadienu Table 8. Determination of LD and LQ values for 1,3-butadiene

\begin{tabular}{|c|c|}
\hline Parametr & Wynik oznaczenia ślepej próby \\
\hline \hline & 0,0020 \\
$x_{i}$ & 0,0020 \\
& 0,0021 \\
& 0,0020 \\
& 0,0020 \\
\hline$s_{p}$ & 0,00004472 \\
\hline $\mathrm{LD}=6 \cdot s_{p}$ & 0,00026 \\
\hline $\mathrm{LQ}=10 \cdot s_{p}$ & 0,00045 \\
\hline
\end{tabular}


Otrzymano wartość granicy wykrywalności 1,3-butadienu w LPG wynoszącą $0,00026 \%(\mathrm{~m} / \mathrm{m})$ oraz wartość granicy oznaczalności wynoszącą $0,00045 \%(\mathrm{~m} / \mathrm{m})$. Norma DIN 51619:2004-02 nie podaje dolnego zakresu stosowalności metody. Z uwagi na zakres stężeń 1,3-butadienu w próbkach przy wyznaczaniu powtarzalności wartość granicy oznaczalności przyjęto jako $0,01 \%(\mathrm{~m} / \mathrm{m})$. Wartości parametrów obliczeniowych potwierdziły możliwość precyzyjnego oznaczania zawartości 1,3-butadienu w skroplonych gazach węglowodorowych na niskich poziomach stężeń, tj. od $0,01 \%(\mathrm{~m} / \mathrm{m})$.

Ostatnim etapem walidacji metody jest wyznaczenie niepewności złożonej metody oznaczania składu LPG według normy DIN 51619:2004-02. W pierwszym etapie szacowania niepewności określono wszystkie składowe niepewności wpływające na niepewność złożoną metody oznaczania 1,3-butadienu w gazach skroplonych LPG.

$\mathrm{Na}$ niepewność związaną z czystością materiału wzorcowego CRM składała się jedynie czystość zastosowanego materiału wzorcowego 1,3-butadienu, o wartości certyfikowanej $(0,2395 \pm 0,0041) \%(\mathrm{~m} / \mathrm{m})$. Niepewność wyniosła $u(P)=0,002367 \%(\mathrm{~m} / \mathrm{m})$.

Wyznaczono niepewność związaną z powtarzalnością wykonywanych oznaczeń. Niepewność tę wyznaczono na podstawie wyników określenia powtarzalności dla wszystkich przebadanych próbek rzeczywistych. Zastosowano uproszczony sposób szacowania niepewności związanej z powtarzalnością oznaczeń, który polegał na oznaczeniu najwyższego odchylenia standardowego uzyskiwanego dla pomiarów powtórzonych na różnych poziomach stężeń. Przy zastosowanym podejściu nie zachodziło ryzyko związane z niedoszacowaniem niepewności. Należy jednak zwrócić szczególną uwagę na odrzucenie wartości odstających. Zbyt wysokie odchylenie standardowe na tle pozostałych odchyleń w dolnym zakresie pomiarowym może doprowadzić do przeszacowania tej wartości niepewności cząstkowej. W przypadku oznaczania 1,3-butadienu najwyższa uzyskana wartość odchylenia standardowego powtarzalności W zakresie pomiarowym wyniosła $0,001577 \%(\mathrm{~m} / \mathrm{m})$ dla zawartości $0,06 \%(\mathrm{~m} / \mathrm{m})$, a zatem niepewność względna przyjęła wartość $u_{w}\left(r_{1,3-\text {-butadien }}\right)=(0,001577 / 0,06) \cdot 100 \%=2,63 \%$ wyniku oznaczenia zawartości 1,3-butadienu w LPG. Niepewność związana z objętością pętli dozującej do dozowania próbki nie miała wpływu na uzyskiwane wyniki oznaczeń z uwagi na zastosowanie metody wzorcowania przez procentową powierzchnię pików oraz wyznaczenie rzeczywistych współczynników wzorcowania. Niepewność związana z odczytem powierzchni pików węglowodorów w LPG była uwzględniona w niepewności związanej z powtarzalnością oznaczeń.

Równanie wyrażające niepewność oznaczania 1,3-butadienu, po uwzględnieniu niepewności związanej z czystością materiałów wzorcowych $u(P)$, powtarzalnością $u_{w}\left(r_{l, 3-\text {-butadien }}\right)$, jak również niepewności odczytu powierzchni pików 1,3-butadienu, przyjęło ostatecznie postać:

$u\left(C_{1,3-\text { butadien }}\right)=C_{1,3-\text { butadien }} \sqrt{\frac{u^{2}(P)}{P^{2}}++u_{w}{ }^{2}\left(r_{1,3-b u t a d i e n}\right)}$

Po podstawieniu wszystkich wartości niepewności cząstkowych do powyższego wzoru obliczono wartość niepewności złożonej oznaczania 1,3-butadienu w LPG:

$$
u\left(C_{1,3-\text { butadien }}\right)=0,028 \cdot C_{1,3-\text { butadien }}
$$

Niepewność rozszerzona $(\mathrm{k}=2, \mathrm{P}=95 \%)$ :

$$
U\left(C_{1,3 \text {-butadien }}\right)=2 \cdot 0,028 \cdot C_{1,3 \text {-butadien }}=0,056 \cdot C_{1,3 \text {-butadien }}
$$

Otrzymana wartość niepewności rozszerzonej oznaczania 1,3-butadienu mieściła się w granicach niepewności rozszerzonej odtwarzalności obliczonej z odtwarzalności podanej w normie DIN 51619:2004-02, co jest wymogiem koniecznym dla laboratoriów badawczych.

\section{Badania handlowych próbek gazu skroplonego LPG pod kątem zawartości 1,3-butadienu}

Na zawartość 1,3-butadienu przebadano 140 próbek handlowych skroplonego gazu węglowodorowego LPG, pochodzących z roku 2019. Odczyt powierzchni pików wykonywano również poniżej granicy oznaczalności, ustalonej na $0,01 \%(\mathrm{~m} / \mathrm{m})$. Zestawienie wyników w \% $(\mathrm{m} / \mathrm{m})$ dla próbek LPG podano w tabeli 9. Do celów porównawczych wyniki podano z dokładnością do $0,001 \%(\mathrm{~m} / \mathrm{m})$.

Tabela 9. Zestawienie próbek LPG badanych pod kątem zawartości 1,3-butadienu

Table 9. Summary of LPG samples tested for 1,3-butadiene content

\begin{tabular}{|l|c|}
\hline \multirow{2}{*}{ Numer kodowy LPG } & Zawartość $\mathbf{1 , 3 - b u t a d i e n u}$ \\
\cline { 2 - 2 } & {$[\mathbf{\%}(\mathbf{m} / \mathbf{m})]$} \\
\hline \hline LPG nr 1, 3, 4, 8-21, 23-54, 56-60, \\
62,63, 66-95, 98-100, 102-110, \\
$\begin{array}{l}\text { 112-114, 116-119, 121, 122, } \\
\text { 124-126, 129, 131-133, 135-140 }\end{array}$ \\
\hline LPG nr 2, 97,128 & $<0,001$ \\
\hline LPG nr 5, 61, 130 & \\
\hline LPG nr 6,7 & 0,012 \\
\hline LPG nr 22, 96 & 0,009 \\
\hline LPG nr 55 & 0,006 \\
\hline LPG nr 64,65, 101, 127 & 0,003 \\
\hline LPG nr 111, 123, 134 & 0,015 \\
\hline LPG nr 115 & 0,002 \\
\hline LPG nr 120 & 0,004 \\
\hline
\end{tabular}


Na przebadanych 140 próbek gazu skroplonego LPG znaczącą większość stanowiły próbki o zawartości 1,3-butadienu na poziomie poniżej $0,001 \%(\mathrm{~m} / \mathrm{m})$ - łącznie 119 próbek. Pozostałą grupę tworzyły próbki o zawartości 1,3-butadienu w zakresie od $0,002 \%(\mathrm{~m} / \mathrm{m})$ do $0,025 \%(\mathrm{~m} / \mathrm{m})$. Tylko 4 próbki przekroczyły wartość $0,01 \%(\mathrm{~m} / \mathrm{m})$. Nie stwierdzono przekroczeń wartości $0,10 \%(\mathrm{~m} / \mathrm{m})$ dla 1,3-butadienu. W celu stwierdzenia, czy występuje zagrożenie związane z występowaniem w LPG tej substancji szkodliwej, konieczne jest jednak przebadanie większej liczby próbek handlowych LPG.

\section{Podsumowanie}

Na podstawie przeprowadzonych badań należy stwierdzić, że jedynie prawidłowo wykonana walidacja lub sprawdzenie możliwości stosowania metody DIN 51619:2004-02 umożliwia precyzyjne oznaczanie niskich zawartości 1,3-butadienu w próbkach LPG. Elementy walidacji metody chromatograficznej badania LPG wysoce wskazane do wykonania w laboratorium badawczym, poza wyznaczeniem czasów retencji i współczynników odpowiedzi oraz rozdzielczości pomiędzy pikami, to powtarzalność w całym zakresie metody, dokładność, odzysk, granice wykrywalności i odtwarzalności oraz niepewność złożona metody. Metoda badawcza oznaczania 1,3-butadienu w LPG zwalidowana w odpowiedni sposób cechuje się wysoką selektywnością. Dzięki zastosowaniu kolumny chromatograficznej ze specjalną fazą stacjonarną CP-AL2O3/KCL zapewniona zostaje wysoka rozdzielczość 1,3-butadienu od pozostałych składników gazu skroplonego LPG. Wskazane wydaje się zastosowanie dozownika typu zawór z pętlą o stałej objętości, który w połączeniu z precyzyjnym ustawieniem przepływu próbki LPG przez pętlę umożliwia uzyskiwanie bardzo dobrej powtarzalności wykonywanych oznaczeń.

Artykuł powstał na podstawie pracy statutowej pt.: Najnowsze metody badań jakości LPG w świetle pracy grupy CEN/TC19/ $W G 23$ - praca INiG - PIB na zlecenie MNSiW; nr zlecenia 0096/ TA/2019, nr archiwalny: DK-4100-0082/2019.

\section{Literatura}

Błaszkiewicz Z., Rogowska D., 2016. LPG - mieszanina propanbutan - aspekty normalizacyjne. Nafta-Gaz, 11: 992-997. DOI: 10.18668/NG.2016.11.14.

Burnus Z., 2009. Walidacja metody oznaczania rozpuszczalnej pozostałości w skroplonych gazach węglowodorowych (LPG) z zastosowaniem chromatografii gazowej. Nafta-Gaz, 8: 636-646.

Burnus Z., 2012. Aspekty badania próbek LPG na podstawie uczestnictwa w krajowych badaniach okrężnych. Nafta-Gaz, 6: 368-376.

Danek B., 2010. Źródła zagrożeń jakości LPG. Nafta-Gaz, 2: 115-120.

Haduch B., 2009. Bezpieczeństwo badań jakości LPG w laboratorium. Nafta-Gaz, 8: 631-635.

Rogowska D., Pałuchowska M., 2009. Wpływ właściwości komponentów gazu skroplonego LPG na jakość produktu finalnego. Nafta-Gaz, 8: 617-649.

\section{Akty prawne i normatywne}

ASTM E 691-19e1 Standard Practice for Conducting an Interlaboratory Study to Determine the Precision of a Test Method.

DIN 51619:2004-02 Testing of mineral oil hydrocarbons Determination of the composition of liquid petroleum gases - Gas chromatographic analysis under special consideration of 1,3-butadiene with mass fractions $\leq 0,1 \%(\mathrm{~m} / \mathrm{m})$.

PN-EN 27941:2015-12 (wersja angielska) Techniczny propan i butan - Analiza metodą chromatografii gazowej.

PN-EN 589:2019-04 (wersja angielska) Paliwa do pojazdów samochodowych - LPG - Wymagania i metody badań.

Rozporządzenie (WE) nr 1907/2006 Parlamentu Europejskiego i Rady z dnia 18 grudnia 2006 r. w sprawie rejestracji, oceny, udzielania zezwoleń i stosowanych ograniczeń w zakresie chemikaliów (REACH) i utworzenia Europejskiej Agencji Chemikaliów, zmieniające dyrektywę 1999/45/WE oraz uchylające rozporządzenie Rady (EWG) nr 793/93 i rozporządzenie Komisji (WE) nr 1488/94, jak również dyrektywę Rady 76/769/EWG i dyrektywy Komisji 91/155/EWG, 93/67/EWG, 93/105/WE i 2000/21/WE.

Rozporządzenie Ministra Energii z dnia 14 kwietnia 2016 r. w sprawie wymagań jakościowych dla gazu skroplonego (LPG) (Dz.U. z 2016 r. poz. 540).

Rozporządzenie Ministra Energii z dnia 17 stycznia 2017 r. w sprawie metod badania jakości gazu skroplonego (LPG) (Dz.U. z 2017 r. poz. 159).

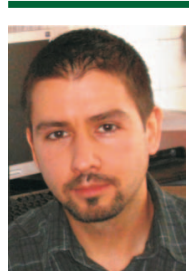

Mgr inż. Zygmunt BURNUS

Asystent w Zakładzie Analiz Naftowych

Instytut Nafty i Gazu - Państwowy Instytut Badawczy

ul. Lubicz 25 A

31-503 Kraków

E-mail: zygmunt.burnus@inig.pl 